J. Clin. Chem. Clin. Biochem.

Vol. 23, 1985, pp. $777-780$

\title{
A Simple Routine Method for SDS-Electrophoresis of Urinary Proteins in Kidney Transplant Patients
}

\author{
By A. Lapin, E. O. Ogunyemi, H. Zyman, F. Gabl \\ Institute for Clinical Chemistry and Laboratory Medicine and \\ J. Zazgornik \\ First Clinic of Medicine, Faculty of Medicine, University of Vienna (Austria)
}

(Received June 24, 1985)

Herrn Prof. Dr. E. Kaiser zum 60. Geburtstag gewidmet

Summary: The molecular weight analysis of urinary proteins can provide useful diagnostic information. For this purpose a routine method of sodium dodecylsulphate polyacrylamide gel electrophoresis (SDSelectrophoresis) is described. The main problem in the introduction of this method into the clinical laboratory lies in the availability of "ready-to-use" electrophoresis gels with good and reproducible quality. A device for gel production is therefore described, which is easily constructed from plastic package materials. Polyacrylamide gels are made batch-wise and in advance. They are suitable for various types and techniques of horizontal electrophoresis. Further, a method for analysis of urinary proteins is described, which permits the simultaneous analysis of 22 unconcentrated urine samples within a 3-hour-electrophoresis run. A specially optimized Coomassie blue staining method (overnight) ensures detection of proteins in the concentration range of milligrams per litre. Electrophoretic analyses were documented by photocopying the finished electrophoresis gels.

Eine einfache Routinemethode zur SDS-Elektrophorese von Harnproteinen bei nierentransplantierten Patienten

Zusammenfassuụung: Die Molekulargewichtsanalyșe von Harnproteinen kann nützliche diagnostische Informationen liefern. Zu diesem Zwecke wird eine Routine-Natriumdodecylsulfat Polyacrylamidgel-Elektrophorese (SDS-Elektrophorese) beschrieben. Die größte Schwierigkeit, diese Methode in das klinische Laboratorium einzuführen, war die Bereitstellung von gebrauchsfertigen Elektrophoresegelen von guter und reproduzierbarer Qualität. Hierzu wird eine Apparatur zur Herstellung von Gelen beschrieben. Sie wurde auf sehr einfache -Weise konstruiert, unter Verwendung von Plastikverpackungsmaterialien.

Die Polyacrylamidgele werden chargenweise und auf Vorrat hergestellt. Sie können für verschiedene Typen und Techniken der horizontalen Elektrophorese verwendet werden. Weiters wird eine Methode zur Harnproteinanalyse beschrieben. Sie erlaubt eine simultane Untersuchung von 22 unkonzentrierten Urinproben innerhalb einer dreistündigen Elektrophorese: Eine speziell optimierte Coomassie Blau-Färbemethode (über Nacht) erlaubt eine Erfassung von Proteinen bis in Konzentrationsbereiche von einigen Milligramm pro Liter. Die Dokumentation von fertigen Analysen wurde durch Photokopieren von fertigen Elektrophoresegelen gewährleistet. 


\section{Introduction}

The analysis of the distribution of urinary proteins according to their molecular weight can provide valuable diagnostic information. As Boesken (11) has shown, the different proteinurias and nephropathies can be diagnosed with the knowledge of the molecular weight spectrum of the various proteins of the urine. However, the introduction of a sodium dodecyl sulphate polyacrylamide gel electrophoresis (SDS-electrophoresis) for this purpose into the clinical laboratory is a slow process, due to technical problems. It is still difficult to obtain within a practicable time a sufficient quantity of electrophoresis gels of satisfactory quality. Industrially made gels are often costly and are available for one apparatus and application only. We present a device for low cost production of glass supported gels suitable for various horizontal electrophoretic techniques.

A charge of 20 gels can be produced and stored for weeks in advance until required for the routine analysis. A simple staining technique ensures a sensitive and reliable evaluation of the urine protein pattern. This method can be used in every laboratory since no special equipment or workshop is required for the gel production.

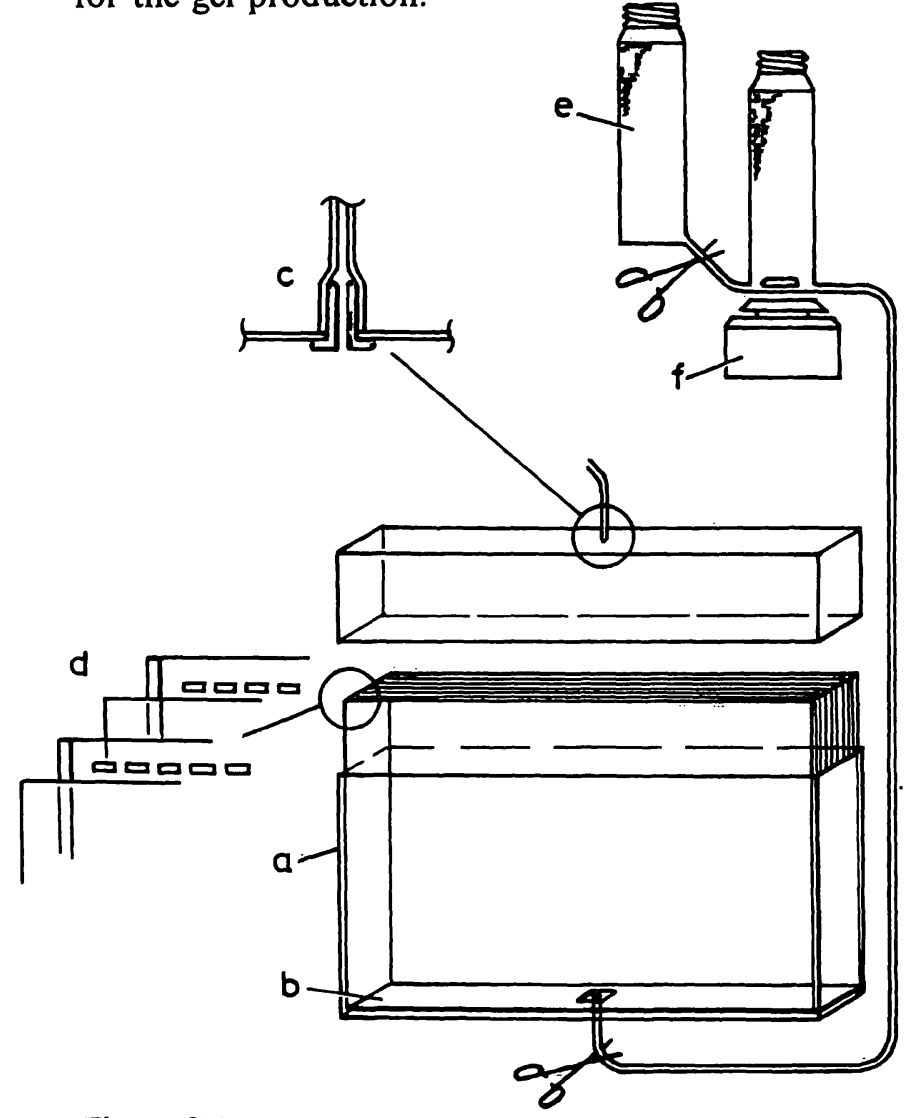

Fig. 1. Gel production apparatus:

a - gel casting box

b - rubber carpet

c - tubing connection

d - glass plates ranged in alternate order

e - gradient former device

$f$ - magnetic stirrer

\section{Materials and Methods}

Chemicals

Acrylamide ( $99.9 \%$ pure) was obtained from Bio Rad (Richmond, CA., USA). N,N,N',N'-tetramethylethylene-diamine (TEMED) was obtained from Sigma (St. Louis, MO., USA). $\mathrm{N}, \mathrm{N}^{\prime}$-methylenediacrylamide (BIS), sodium dodecyl sulphate (SDS), Tris-(hydroxymethyl)-aminomiothane (TRIS), Coomassie brillant Blue R-250 and G-250 and all other reagents and solvents of analytical purity were obtained from Merck (Darmstadt, FRG), unless stated otherwise. For the molecular weight calibration, high molecular weight (HMW) and low molecular weight (LMW) protein standards from Pharmacia Fine Chemicals A. B. (Uppsala, Sweden) were used. "Bind Silan ${ }^{\circledR "}$ and "Repel Silan ${ }^{\circledR} "$ solutions for the treatment of glass plates were obtained from LKB-Produkter A. B. (Bromma, Sweden).

\section{Buffers}

\section{A) Gel buffer $1.5 \mathrm{~mol} / \mathrm{l}$ TRIS- $\mathrm{HCl} \mathrm{pH} 8.8$}

TRIS $(18.17 \mathrm{~g})$, SDS $(0.4 \mathrm{~g})$ and $\mathrm{NaN}_{3}(0.010 \mathrm{~g})$ were dissolved in distilled water $(80 \mathrm{ml})$; after adjustment of the $\mathrm{pH}$ to 8.8 with $\mathrm{HCl}$, the volume was made up to $100 \mathrm{ml}$ with distilled water.

B) Electrode buffer stock solution (Laemmli, (4))

TRIS (30.28 g), glycine (144.0 g), SDS (10:0 g) and $\mathrm{NaN}_{3}$ $(0.10 \mathrm{~g})$ were dissolved in distilled water and made up to 1 liter.

C) Cathode electrode buffer 0.375 molll TRIS-glycine pH 8.3 Mix $100 \mathrm{ml}$ of electrode buffer stock solution with $900 \mathrm{ml}$ of distilled water.

D) Anode electrode buffer 0.375 molll TRIIS-glycine pH 8.3 Mix $100 \mathrm{ml}$ of electrode buffer stock solution and $188 \mathrm{ml}$ glycerol $(870 \mathrm{~g} / \mathrm{l})$ and make up to 1 liter with distilled water.

E) Sample buffer

Gel buffer (A) $(2.5 \mathrm{ml})$, and SDS ( $4.0 \mathrm{~g})$ are made up to $100 \mathrm{ml}$ with distilled water. A few crystals of bromphenol blue are added to make the sample visible on the gel.

F) Acrylamide solution

Acrylamide $(64.24 \mathrm{~g})$, BIS (1.76 g), glycerol $(870 \mathrm{~g} / \mathrm{l})(55 \mathrm{ml})$ are dissolved in distilled water, made up to $220 \mathrm{ml}$, then filtered.

\section{Gel production device}

The main part of the gel production device was the gel casting box made from a plastic container with dimensions of $210 \times$ $130 \times 70 \mathrm{~mm}$ (fig. 1). The bottom and top of the casting box were fitted to the plastic tubings (inlet and outlet) using plastic ends of injection needles.

The bottom of the box was covered by a "rubber carpet", $1 \mathrm{~mm}$ thick, in order to ensure correct filling of the box by the appropriate acrylamide solution. Further, the casting box contained glass plates $205 \times 110 \times 1 \mathrm{~mm}$ dimension. One half of the glass plates (gel supporters) treated with "Bind Silan ${ }^{\otimes "}$ solution were arranged in alternate order with the other half of the glass plates (gel formers). Gel formers, being treated with "Repel Silan ${ }^{\circledR}$ " solution, had affixed on their shorter edges several layers of "Dymo ${ }^{\otimes}$ " tape in order to form side spacers of $0.8 \mathrm{~mm}$. For the routine density gradient SDS-electrophoresis, the gel formers each carried twenty six $1 \mathrm{~mm} \times 5 \mathrm{~mm}$ slot formers made from "Dymo ${ }^{\oplus}$ " tape. The closed casting box was sealed with cellotape and connected by the bottom plastic tubing (inlet) to the gradient former device, situated $40 \mathrm{~cm}$ higher. The gradient former was made from two cylindrical plastic flasks connected by plastic tubing as indicated in figure 1. Surgical forceps were used for flow regulation. The first flask with a magnetic stirrer was f̣iled with $250 \mathrm{ml}$ of "light". 
acrylamide solution, the second flask with the same volume of "heavy" acrylamide solution. The "heavy" solution contained the acrylamide solution (F) $(167.67 \mathrm{ml})$, the gel buffer (A) $(62.5 \mathrm{ml})$ and distilled water $(19.83 \mathrm{ml})$. The "light" solution contained the acrylamide solution (F) $(33.33 \mathrm{ml})$, the gel buffer (A) $(62.5 \mathrm{ml})$ and distilled water $(154.17 \mathrm{ml})$. Both "light" and "heavy" acrylamide solution were degassed for 10 minutes before being poured into the gradient former. Then $70 \mu$ TEMED and $200 \mu \mathrm{l} 400 \mathrm{~g} / \mathrm{l}$ ammonium peroxodisulphate were added to each as polymerization starter. A density gradient was formed in the casting box with the acrylamide concentration ranging from 40 to $200 \mathrm{~g} / \mathrm{l}$. The box was filled from the bottom to the top just by hydrostatic pressure. After overnight polymerization, the casting box was opened. The gel plates were removed, separated from one another using a spatula and wrapped in polypropylene foil using a frozen food bag sealer and finally stored at $4{ }^{\circ} \mathrm{C}$. Gels stored in the described manner showed no deterioration for at least 5 weeks and some were used after 3 months.

The homogeneity and reproducibility of the density gradient were checked by adding a colourant. bromphenol blue, to the heavy solution and scanning densitometrically the increasing colour intensity in a gel. The reproducibility was usually better than $95 \%$ within a charge of 20 gels. The gel casting box can also be used for the production of other types of gel. For the two dimensional electrophoresis according to the method of Görg et al. (2) the gel slot former was made by affixing additionally, a one $5 \mathrm{~mm}$ wide strip of "Dymo ${ }^{\circledR}$ " tape along the longer edges of the gel former plates instead of twenty six $1 \mathrm{~mm} \times 5 \mathrm{~mm}$ strips.

For the production of gels for isoelectric focusing, only one reservoir of $500 \mathrm{ml}$ is used instead of the gradient former. The reservoir is then filled by a solution containing $40 \mathrm{~g} / \mathrm{l}$ acrylamide and $2.5 \mathrm{~g} / \mathrm{l} \mathrm{BIS}$. The remaining procedure for gel production is identical to that described above. Just before the isoelectric focusing, the prepared gel must be incubated in a appropriate solution containing urea and ampholine of the desired $\mathrm{pH}$ range. The isoelectric focusing is then performed as described elsewhere (3).

\section{SDS electrophoresis of urinary proteins}

The urine samples were 4 hour samples collected from the patients during out-patient check-ups at the clinic and in the wards. No preservatives were added, but the urines were collected unter sterile conditions. They were analysed on the same day or stored deep frozen till analysed. Deep freezing did not affect the protein pattern in the urines as demonstrated by comparing repeated analysis of frozen samples with their analysis when fresh. Prior to the SDS electrophoresis the total urinary protein concentration was measured by using the commercial "Bio=Rad-Protein Assay".

One hundred microlitres of each sample were mixed with equal volumes of sample buffer (E). Proteín standards (HMW and LMW) were dissolved in $200 \mu \mathrm{l}$ of the same buffer, with a small quantity Coomassie blue R-250 added as a marker. All were incubated at room temperature for at least 30 minutes. Then $2.5 \mu \mathrm{l}$ of each treated sample and of the standards were applied to the gel slots, in order to accommodate 22 patient samples per gel. The flat-bed electrophoresis was then carried out using the LKB "Multiphor System" with a constant power and "Multi Temp Thermostatic Circulator" (LKB Produkter AB, Bromma, Sweden). Laemmli (4) electrode buffers of the composition described above, cathode (C) and anode (D) electrode buffers were used. The voltage was set at 500 volts, the current at maximum and a power of 15 watt per gel. The electrophoresis was stopped when the marker (Coomassie. blue R-250 in the protein standards) was $1 \mathrm{~cm}$ from the anode end of the gel. This took usually about 3 hours.

\section{Staining}

The gels were stained overnight in $1 \mathrm{~g} / \mathrm{l}$ Coomassie brillant blue R-250 in $35 \mathrm{~g} / 1$ perchloric acid. The staining takes about 5 hours but this time can be reduced by gentle shaking. The gels were destained in $150 \mathrm{~g} / \mathrm{l}$ acetic acid for 1 hour, rinsed with water and sealed in polypropylene foil. Documentation of runs was achieved by photocopying the gel plates, cutting out the relevant strip from the photocopy and affixing them to the special result sheets for the patients. The solution of $1 \mathrm{~g} / \mathrm{l}$ Coomassie brillant blue R-250 in $35 \mathrm{~g} / \mathrm{l}$ perchloric acid was chosen after trying out the following staining solutions:

a) $0.4 \mathrm{~g} / 1$ Coomassie blue $\mathrm{G}-250$ in a mixture of $35 \mathrm{~g} / 1$ perchloric acid and $100 \mathrm{~g} / 1\left(\mathrm{NH}_{4}\right)_{2} \mathrm{SO}_{4}$ according to the suggestions of Neuhoff (5).

b) $0.4 \mathrm{~g} / 1$ Coomassie blue G-250 in $35 \mathrm{~g} / 1$ perchloric acid,

c) $1 \mathrm{~g} / 1$ Coomassie blue R-250 in $35 \mathrm{~g} / 1$ perchloric acid,

d) $5 \mathrm{~g} / \mathrm{l}$ Coomassie blue R-250 in $100 \mathrm{~g} / \mathrm{l}$ acetic acid,

e) $5 \mathrm{~g} / 1$ Coomassie blue R-250 in a mixture of acetic acid and $450 \mathrm{~mol} / \mathrm{l}$ ethanol.

Coomassie blue R-250 (1 g/l) in perchloric acid $(35 \mathrm{~g} / \mathrm{l})$ was found to be the most sensitive, revealing otherwise weak or absent bands, and proteinuria down to a concentration of 20 $\mathrm{mg} / \mathrm{l}$ can be detected (fig. 2 ). It was possible to detect nanogram quantities of protein applied in the $2.5 \mu \mathrm{l}$ of the treated samples applied to the gel. There was also little or no staining of the background. The second best was $0.4 \mathrm{~g} / 1$ Coomassie blue G250 in $35 \mathrm{~g} / \mathrm{l}$ perchloric acid.

\section{Results and Discussion}

This method can be carried out routinely with ease and it is already in routine use in the laboratory of the authors. With the aid of the gel production device, 20 gel plates could be cast in advance and stored till required. The gel production device itself was made in a very simple way, using plastic package material, which can be found in every laboratory. It can be adapted for any kind of horizontal electrophoresis using polycrylamide gels, such as isoelectric focussing, SDS-electrophoresis (fig. 2), two dimensional electrophoresis or isoelectric focusing with immobilized $\mathrm{pH}$ gradients. The preparation of one charge of at least 20 gels can easily be made by one person within one hour (completed by overnight polymerization). Since the cost for gel preparation results mostly from the chemicals required, the cost for a gel plate does not exceed 2 US dollars.

Using the described equipment for horizontal electrophoresis, two electrophoretic runs if necessary could be carried out simultaneously, equivalent to the handling of $\mathbf{4 4}$ patient samples per day. This can be done easily by a single person within a working day, still leaving time for other tasks.

The method rendered unneccessary the concentration of weakly proteinuric samples below $1 \mathrm{~g} / \mathrm{l}$ (1) which 


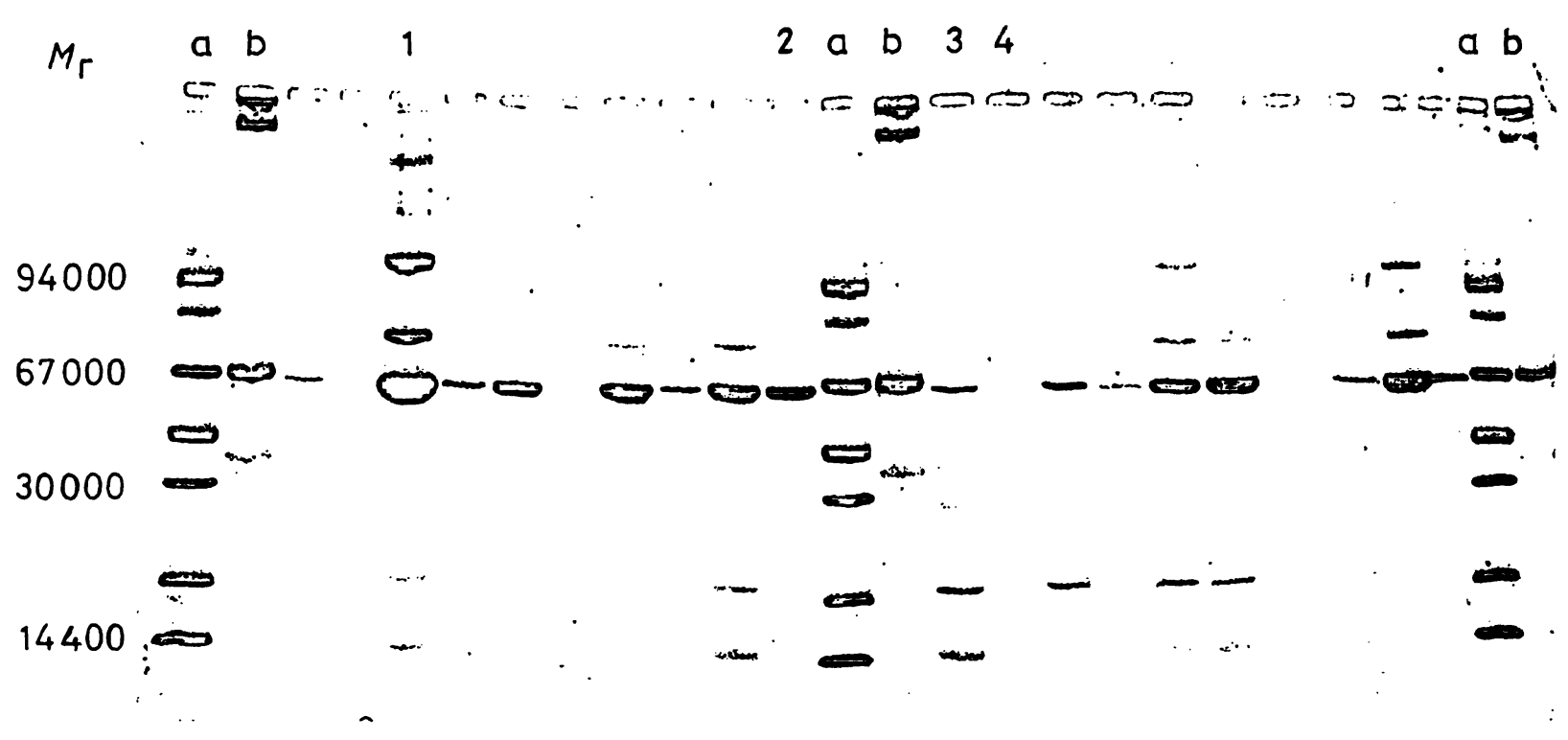

Fig. 2. A typical gel representing an analysis of 20 urine samples together with three HMW (a) and LMW (b) standards. The application slots are seen on the top of the picture; the front of the electrophoretic run on the bottom. The albumin bands are situated along the mid line of the gel. Some interesting urine samples:

1) mixed proteinuria (protein $3.2 \mathrm{~g} / \mathrm{l}$ )

2) selective glomerular proteinuria (protein $0.9 \mathrm{~g} / \mathrm{l}$ )

3) tubular proteinuria (protein $0.7 \mathrm{~g} / \mathrm{l}$ )

4) physiological proteinuria (protein $50 \mathrm{mg} / \mathrm{l}$ )

a) HMW - high molecular weight standard

b) LMW - low molecular weight standard

include clinically relevant cases. Proteinuria down to $20 \mathrm{mg} / \mathrm{l}$ could be detected (fig. 2). This saved time and avoided losses of specific proteins caused by the concentrating procedures. Mercaptoethanol was omitted from the SDS-sample buffer in order not to destroy the physiological structure of the proteins by splitting them into subunits; this is important because the kidney handles different proteins mainly bei their size (1). The chosen staining method, $1 \mathrm{~g} / 1$ Coomassie blue R-250 in $35 \mathrm{~g} / 1$ perchloric acid followed by destaining in $150 \mathrm{~g} / \mathrm{l}$ acetic acid, can detect nanogram quantity of protein. It is however less sensitive than silver staining which can detect as little as 0.01 nanogram of protein per square millimeter (6), but more simple to handle and reliable since no special chemical like silver nitrate or high purity water is required. The described method satisfies the needs of routine, as well as research electrophoresis with a minimum of costs, equipment and materials. The main advantage in comparsion to already published procedures (7) or commercially aviable systems is that it permits the production of polycrylamide gels of good quality suitable for different types of electrophoretic chambers and for different electrophoretic techniques.

\section{References}

1. Boesken, W. H. (1981) In: Electrophoresis 81 (Allen, R. C. \& Arnaud, P., eds.) Walter de Gruyter \& Co, Berlin, New York: pp. 453-462.

2. Görg, A., Postel, W. \& Westermaier, R. (1981) In: o. c. (1), pp. 259-270.

3. Lapin, A., Endler, A. T., Ogunyemi, E. O. \& Gabl, F. (1984) J. Clin. Chem. Clin. Biochem. 22, 53-59.

4. Laemmli, U. K. (1970) Nature 227, 680-685.
5. Neuhoff, V. \& Stamm, R. (1984) In: Electrophoresis '84 (Neuhoff, V., ed.) Weinheim, Deerfield Beach, Florida, Basel: pp. $317-319$.

6. Merril, C. R., Goldmann, D., Sedman, S. \& Ebert, M. H. (1981) Science 211, 1437-1438.

7. Batsudaira, P. T. \& Bugess, D. R. (1978) Anal. Biochem. 87, 386-396.

DDr. Alexander Lapin Institut für Klinische Chemie und Laboratoriumsdiagnostik Universität Wien

Lazarettgasse 14 A-1090 Wien Österreich 